\title{
Unusual observations during construction of a new cloning vector providing lon gene expression in Escherichia coli
}

\author{
K. Friehs * and J.E. Bailey \\ Department of Chemical Engineering, California Institute of Technology, Pasadena, CA 91125, U.S.A. \\ (Received 1 February 1988; accepted 19 December 1988)
}

\section{Summary}

The plasmid pJMC40 containing the lon gene was transformed into $E$. coli HB101 leading to clones with either pJMC40 or a large plasmid designated pJMC40ins. pJMC40ins has a $1.3 \mathrm{~kb}$ DNA insert outside of the lon operon. Attempts to reduce the size of pJMC40 through circularization of a $6.7 \mathrm{~kb} E c o \mathrm{RI}$ fragment containing the lon operon and larger parts of pBR322 failed. Circularization of an $8.0 \mathrm{~kb} E c o$ RI fragment of pJMC40ins, consisting of the $6.7 \mathrm{~kb}$ fragment and the $1.3 \mathrm{~kb}$ insert, produced a new plasmid which is useful as a small vector with a functional lon operon. The lon gene was cloned in vitro into the vector pUC18 setting it under the control of the lac promotor. Different attempts to transform this construct into $E$. coli failed. We suggest that the expression level of lon is very crucial for the viability of $E$. coli cells. Changes in regulation of lon expression expected to elevate La activity are lethal for $E$. coli.

\section{Introduction}

Several different proteases have been described in E. coli (Goldberg et al., 1981). One of these, the protease La (a $94 \mathrm{kDa}$ polypeptide), was identified as the gene product of the lon gene, also called capR (Zehnbauer et al., 1981; Schoemaker and

Correspondence to: J.E. Bailey, Department of Chemical Engineering, California Institute of Technology, Pasadena, CA 91125, U.S.A.

* Present address: Institut für Technische Chemie der Universität Hannover, Callinstrasse 3, D-3000 Hannover 1, F.R.G. 
Markovitz, 1981; Chung et al., 1983). On an evolutionary basis, lon has been shown to be an ancient gene, found in such different bacteria as Caulobacter crescentus CB13 and Halobacterium halobium R1 (Rupprecht and Markovitz, 1983). The lon gene is involed in the regulation of capsular polysaccharide synthesis (Trisler and Gottesman, 1984) and determines the half-life of a regulator protein involved in this biosynthetic pathway (Gottesman et al., 1985a). Therefore, lon mutants appear as highly mucoid colonies on solidified media.

Lon also interacts with bacteriophages in infected cells and has been shown to affect the level of $\gamma$-repressor (Truitt et al., 1976). Infection by T4, T5 or T7 leads to decrease in the extent of lon-linked degradation of abnormal proteins (Simon et al., 1978).

Another function of lon is seen in cell division, in which lon controls the half-life of the cell division inhibitor SulA (Belhumeur and Drapeau, 1984). E. coli lon mutants exhibit an increased stability of SulA, thus inhibiting cell division by inhibiting FtsZ, an essential cell division protein (Lutkenhaus et al., 1986). The UV sensitivity of lon mutants is connected with the regulation of the half-life of the SulA protein by the lon gene product. UV induces the synthesis of SulA, which interferes with SulB, leading to inhibition of cell septation. If SulA is not degraded by the protease La, accumulation of SulA blocks cell septation and leads to lethal filamentation (Gottesman et al., 1985b).

A well-described function of $\mathrm{La}$ is the ATP-dependent degradation of normal and abnormal proteins (Edmunds and Goldberg, 1986). Incubating large proteins with purified protease La results in polypeptides which are larger than $1500 \mathrm{Da}$. This and other data suggest that La protease activity is the rate-limiting step in the breakdown of abnormal proteins (Goldberg, 1985). Some results show that addition of DNA enhances ATP hydrolysis and that protease La apparently binds to DNA. It is possible that the binding of La to DNA has a significant influence on regulation of degradation of proteins (Chung and Goldberg, 1982).

The protease La belongs to the so-called 'heat-shock' proteins. It was shown that a shift to high temperature increased the rate of protein degradation. La appears to be synthesized at a higher rate under stress conditions where the "heat-shock response' is induced (Goff et al., 1984). The production of abnormal proteins, which are a main target for the lon gene product, stimulates the transcription of lon and other heat-shock genes (Goff and Goldberg, 1985). Comparison of the regulatory region of lon with known heat-shock regulatory regions shows possible consensus sequences (Gayda et al., 1985).

The $E$. coli protein degradation system can decrease the yield of cloned proteins. LacZ fusion proteins (Cheng et al., 1981) and abnormal proteins are more stable in lon mutants (Zipser and Bhavsar, 1976). It is thus very likely that lon is involved in the degradation of foreign cloned proteins. Many low molecular weight proteins, such as cloned human insulin, as well as some viral envelope proteins produced in E. coli, have been found to be degraded rapidly (Bröker, 1986).

However, there is some evidence that the protease La may not participate in the degradation of certain cloned proteins, such as interferon $\alpha \mathrm{A}$ in $E$. coli (Kitano et al., 1987). Some lon mutations do not affect the energy-dependent degradation of 
proteins under starvation, as would be expected if La were the only ATP-dependent protease (Maurizi et al., 1985). Subsequent studies have identified other ATP-dependent proteases in E. coli (Katayama-Fujimura et al., 1987; Hwang et al., 1987).

The lon gene has been cloned from a new $\mathrm{F}^{\prime}$ factor (Zehnbauer and Markovitz, 1980). The plasmid pJMC40 has the lon gene under the control of its own promoter (Schoemaker and Markovitz, 1981). To find out more about the specific involvement of lon in the degradation of recombinant fusion proteins and abnormal proteins, such as $\beta$-galactosidase nonsense fragments, we have formulated new smaller plasmid vectors containing the lon gene. These will enable study of the effects of placing more copies of the lon gene in $E$. coli and facilitate future manipulations of the lon gene. Also, the attempt was made in this work to place the lon structural gene under the regulation of a controllable promoter such as the lac promoter. The host-vector system chosen for in vitro manipulation of the lon gene was the very well developed pUC vector family and their adapted hosts such as $E$. coli DH5 $\alpha$ and $E$. coli JM101 (Yanisch-Perron et al., 1985). The pUC vectors have a very useful multicloning site immediately behind the lac promoter, a few amino acids into the lac $Z$ structural gene. By $\alpha$-complementation with a lac $Z$ fragment produced by the host, it is very easy to detect clones with inserts in the multicloning site (Vieira and Messing, 1982). With an inducible lon gene, controlled expression of the protease La could aid in studying the regulation system in which lon is involved and would also allow the study of the kinetics of degradation of several different proteins at different levels of La activity. In this report, we present some unusual observations during these cloning studies and show evidence that the cell function is highly sensitive to the expression level of lon.

\section{Materials and Methods}

Bacterial strains, plasmids, cloning vectors, media and culture conditions

Competent cells of $E$. coli HB101 and $E$. coli DH5 $\alpha$ were purchased from BRL. Competent cells of E. coli JM101 $\left(F^{\prime} l a c I^{q}\right)$ were purchased from Clontech, CA. The lon mutant $E$. coli BU886 was a gift from Ahmad Bukari. The lon mutant $E$. coli RGC123 and the plasmid pJMC40 were obtained from A. Markovitz. The cloning vectors pUC13, pUC18 and pUC19 were purchased from Pharmacia.

Bacterial growth was carried out routinely at $30^{\circ} \mathrm{C}$ or $37^{\circ} \mathrm{C}$ in LB medium $(10 \mathrm{~g}$ $1^{-1}$ bactotryptone, $5 \mathrm{~g}^{-1}$ yeast extract and $\left.5 \mathrm{~g}^{-1} \mathrm{NaCl}\right)$. To select plasmid-containing colonies, tetracycline $\left(10 \mathrm{mg}^{-1}\right)$ or ampicillin $\left(100 \mathrm{mg}^{-1}\right)$ were added. As medium after transformation, S.O.C. medium $\left(20 \mathrm{~g} \mathrm{l}^{-1}\right.$ bactotryptone, $5 \mathrm{~g} \mathrm{l}^{-1}$ yeast extract, $10 \mathrm{mM} \mathrm{NaCl}, 2.5 \mathrm{mM} \mathrm{KCl}, 10 \mathrm{mM} \mathrm{MgSO}, 10 \mathrm{mM} \mathrm{MgCl}, 20 \mathrm{mM}$ glucose) or M9 mineral salts medium (Miller, 1971) supplemented with essential amino acids $\left(20 \mathrm{mg} \mathrm{l}^{-1}\right)$ and thiamine $\left(1 \mathrm{mg}^{-1}\right)$ with glycerol as the carbon source was used. The M9 mineral salts medium was also used to determine mucoid or non-mucoid growth on solidified media. Media were usually solidified by the addition of $1.5 \%$ agar. 
$D N A$ preparation and cloning techniques

Large-scale DNA preparation was done by $\mathrm{CsCl}$ /ethidium bromide (EtBr)-gradient centrifugation of cell lysates prepared by alkaline lysis of cells as described in Maniatis et al. (1982). After removal of EtBr by extraction with water-saturated $n$-butanol, the DNA was dialyzed against TE buffer (10 mM Tris, 1 mM EDTA, pH 8.0 ) and concentrated by ethanol preparation. DNA preparations were stored in TE buffer at $4^{\circ} \mathrm{C}$ or at $-20^{\circ} \mathrm{C}$.

Minipreparations of plasmid DNA from E. coli strains for rapid analysis of clones were obtained by the alkaline lysis method of Birnboim and Doly (1979) with slight modification or by the method of Ish-Horowics and Burke (1981).

Restriction endonucleases were purchased from BRL, Pharmacia, Boehringer and New England Biolabs. They were used under conditions recommended by the suppliers by using either $10 \times$ buffers described in Maniatis et al. (1982) or $10 \times$ buffers obtained from the suppliers. Ligase was purchased from Pharmacia and used with the ligation buffer described in Maniatis et al. (1982) or was purchased from BRL and used with the $5 \times$ buffer supplied with the enzyme. The transformation procedure was obtained from the BRL product profile for competent cells.

Gel electrophoresis and isolation of DNA from agarose gels

Agarose gels, normally in the range of $0.8-1.0 \%$ agarose, were usually run in the subcell mode. A tris-borate buffer $(89 \mathrm{mM}$ Tris, $89 \mathrm{mM}$ boric acid, $2.5 \mathrm{mM}$ EDTA, $\mathrm{pH} 8.0)$ or a Tris-acetate buffer $\left(50 \times\right.$ stock solution: $242 \mathrm{~g}^{-1}$ Tris, $57.1 \mathrm{ml}^{-1}$ glacial acetic acid, $16.8 \mathrm{~g}^{-1}$ EDTA, $\mathrm{pH} 8.0$ ) was used.

Isolation of DNA fragments from agarose gels was performed by several different methods. After using low melting point agarose to separate the DNA fragments, either the phenol extraction method or the elutip-r minicolumn method from Schleicher and Schuell was used for DNA isolation. In attempts to improve the yield of DNA recovery, DEAE cellulose (NA45 from Schleicher and Schuell) was placed behind DNA bands in the gel and, after running the DNA into the membrane, the fragments were released with a high salt buffer. An improvement in recovery was achieved by using the gene-clean method from BIO 101 in which a silicate matrix is used to bind DNA in a high molar $\mathrm{NaI}$ solution. Addition of $\mathrm{NaI}$ allows agarose gel pieces to melt at $65^{\circ} \mathrm{C}$. DNA release is achieved using very low salt buffers, allowing the use of the DNA for other modification immediately after isolation.

\section{Results}

The plasmid pJMC40 was constructed by combining the Pst I cut plasmid pBR322 with an approximately $9.7 \mathrm{~kb}$ Pst I fragment of the plasmid pBZ303 (Schoemaker and Markovitz, 1981). The $9.7 \mathrm{~kb}$ fragment contains the plasmid pHA105 (Avni and Markovitz, 1979) with pieces of chromosomal E. coli DNA attached on both ends. One of these chromosomal DNA fragments contains the lon gene. 

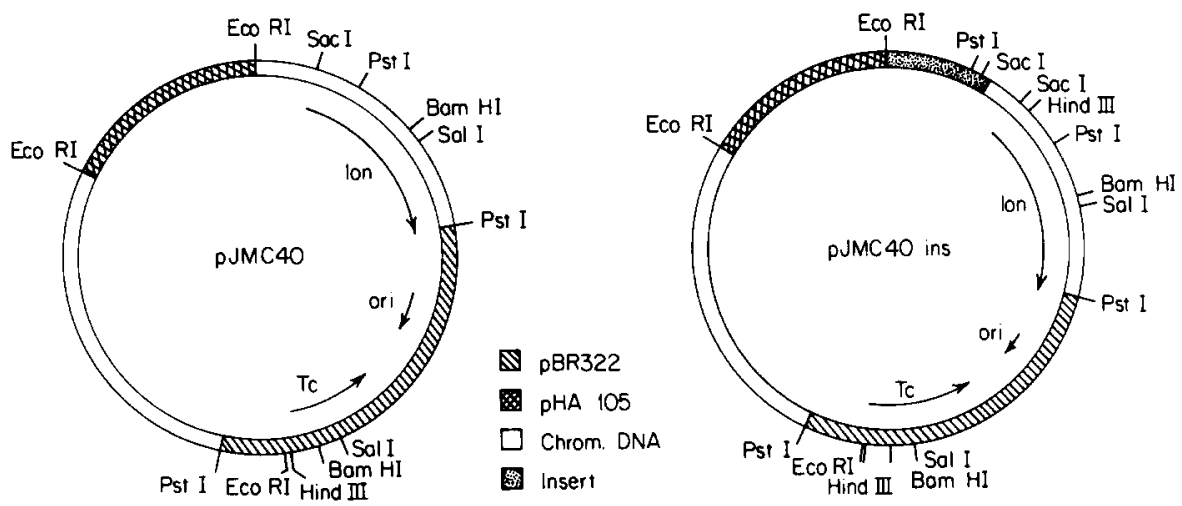

Fig. 1. Restriction map of pJMC40 and pJMC40ins. pJMC40 consists of the vectors pHA105 and pBR322 and two $E$. coli chromosomal DNA fragments. After transformation of $E$. coli HB101 with pJMC40 and isolation of the plasmid DNA, a mixed population of plasmids was found: pJMC40 and a larger plasmid, pJMC40ins. It was shown that the larger plasmid is equivalent to pJMC40 with a $1.3 \mathrm{~kb}$ DNA insert in the chromosomal DNA fragment which bears the lon gene. The insertion is not in the lon operon, and lon negative strains transformed with pJMC40ins exhibited lon positive phenotypes.

pJMC40 was transformed into $E$. coli $\mathrm{HB} 101$ and plasmid DNA was isolated by a miniprep method using a single colony of the obtained transformants. To find the orientation of pBR322 in pJMC40, the plasmid was cut with EcoRI. There are two possible restriction patterns, each consisting of 3 fragments: either a $2.5 \mathrm{~kb}$, a $4.9 \mathrm{~kb}$ and a $6.7 \mathrm{~kb}$ fragment or a $2.5 \mathrm{~kb}$, a $3.9 \mathrm{~kb}$ and a $7.7 \mathrm{~kb}$ fragment. The former pattern was found, and therefore, the map of pJMC40 was established as shown in Fig. 1.

However, the restriction pattern also resulted in an additional band at $8.0 \mathrm{~kb}$ (Fig. 2). Since combinations of the various fragments do not result in a fragment of this size, partial digestion is not the cause for such a pattern. After transforming $E$. coli DH5 $\alpha$ with a plasmid sample from the first miniprep and analyzing some of the resulting tetracycline-resistant transformants, two different plasmids were identified: the expected pJMC40 and a different plasmid, designated here pJMC40ins, with a $1.3 \mathrm{~kb}$ insert. Further restriction analysis with HindIII, Pst I, BamHI, SacI, Sal I, and their combinations, showed that the insert was outside of the lon coding region. Additional restriction sites for $S a c I$ and $P s t \mathrm{I}$ were found in this insert (Fig. 1).

To determine the lon function of both plasmids, each of them was transformed into the lon-negative strains $E$. coli BU886 and $E$. coli RGC123. The phenotype of the resulting transformants changed from highly mucoid to non-mucoid colony forms, indicating that the lon function is expressed in both pJMC40 and pJMC40ins.

Plasmids pJMC40 and pJMC40ins are both too large and have too many restriction sites to be used as possible vectors for cloning additional DNA. Therefore an attempt was made to construct a smaller lon-containing plasmid by digesting 


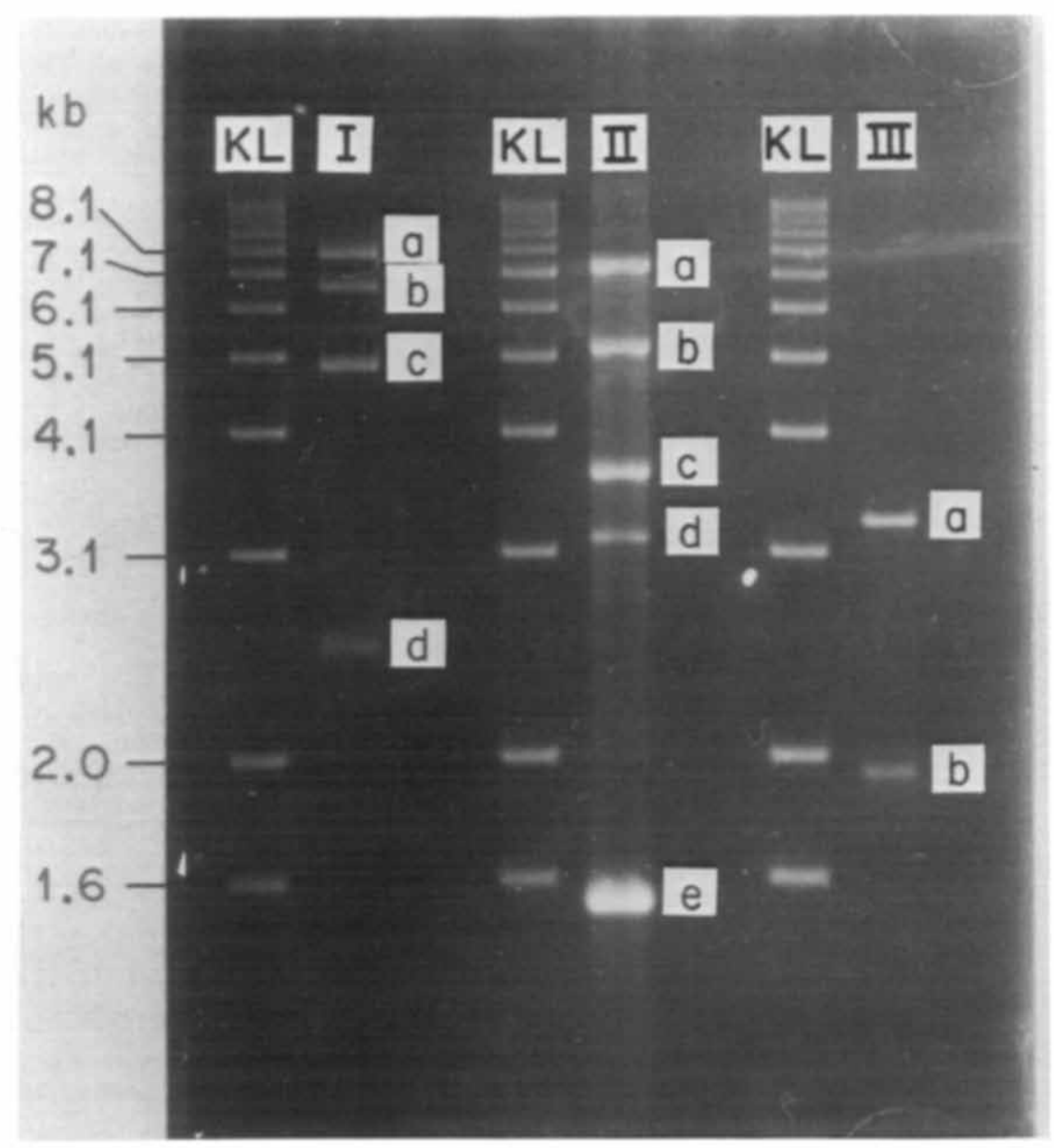

Fig. 2. Gel electrophoresis of different endonuclease digestions: $0.9 \%$ agarose, TAE buffer, $60 \mathrm{~mA}$. (KL) Molecular weight standard; the "1 kb ladder" purchased from BRL; $0.15 \mathrm{mg}$ per lane. (I) Eco RI digest of pJMC40 plasmid isolation after transformation into E. coli HB101; b, c, d represent expected bands of the $6.7 \mathrm{~kb}, 4.9 \mathrm{~kb}$ and $2.5 \mathrm{~kb}$ fragments; a represents an additional fragment at $8.0 \mathrm{~kb}$ consisting of the $6.7 \mathrm{~kb}$ fragment and a $1.3 \mathrm{~kb}$ insert. (II) Sall digest of a precipitated ligation between pUCflon2 (the Pst I/Sal I fragment of the lon gene, cloned into pUC18, see Fig. 3) and flon1 (the SacI/SalI fragment of the lon gene, see Fig. 3.): a, dimer of pUCflon 2; b, pUClon $(5.2 \mathrm{~kb}$, the linearized in vitro construction of pUC18 with the lon gene under the lac promoter); c, monomer of pUCflon2; d, dimer of flon1; e, monomer of flonl. (III) Pst I digest of religated $5.2 \mathrm{~kb}$ fragment (pUClon, see IIb): a, pUC (2.67 kb) with the $0.58 \mathrm{~kb} \mathrm{Sacl} / P_{s t} \mathrm{I}$ fragment of the lon gene; $\mathrm{b}$, the $1.95 \mathrm{~kb}$ Pst $\mathrm{I} /$ Pst I fragment of the lon gene.

pJMC40 with EcoRI and religating the $6.7 \mathrm{~kb}$ fragment. Such a religate would contain the origin of replication and the tetracycline resistance genes from pBR322 (Fig. 3). Although the religation was confirmed by restriction analysis and gel electrophoresis and a large amount of religated DNA was used for transformation into $E$. coli HB101, no transformants could be obtained. 

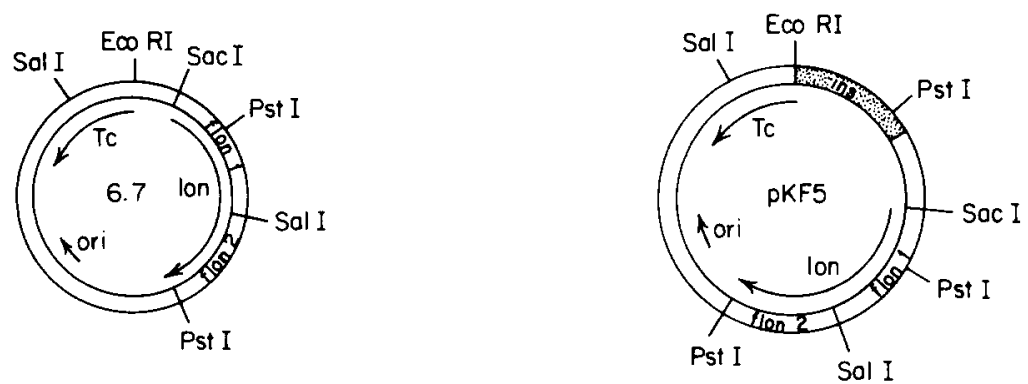

Fig. 3. Restriction map of the hypothetical circularized $6.7 \mathrm{~kb}$ fragment of pJMC40 and the religated 8.0 $\mathrm{kb}$ Eco RI fragment of pJMC40ins, designated pKF5. In several attempts, religated $6.7 \mathrm{~kb}$ fragments were transformed into $E$. coli HB101 but no transformant could be obtained. Some reasons for this result are discussed in the text. After transformation of pKF5 into $E$. coli HB101, tetracyclin-resistant clones were obtained and isolated plasmids were confirmed to be the religated $8.0 \mathrm{~kb}$ fragment. Lon-negative strains transformed with pKF5 showed lon-positive phenotype, indicating expression of the lon gene on pKF5. The fragments flon 1 and flon 2 are marked. With those fragments and pUC18 as vector, the plasmid pUClon, which contains the lon gene under the control of the lac promoter, was constructed in vitro. pKF5 is useful as a cloning vector with a functional lon operon.

The same procedure was performed using the $8.0 \mathrm{~kb} E c o$ RI fragment (Fig. 3). Transformation in $E$. coli $\mathrm{HB101}$, after religation and verification, led to some tetracycline-resistant colonies. Analysis of isolated plasmid DNA showed that, in this case, the construction resulted in a stable plasmid. The new plasmid, designated pKF5, was transformed into $E$. coli BU886 and $E$. coli RGC123. The tetracyclineresistant transformants showed the same phenotypic change from highly mucoid to non-mucoid colony forms as did transformants of the same strains with pJMC40 and pJMC40ins. Therefore pKF5 has an expressed lon function.

In an attempt to change the control of the lon gene expression, the nucleotide sequence between the EcoRI site and the HindIII site of the $6.7 \mathrm{~kb}$ fragment (Gayda et al., 1985) was examined for a possible restriction site as close as possible to the lon start codon. For this search, a computer program developed by A. Seressiotis was used. A $S a c$ I site was found immediately preceding the beginning of the structural gene and a Pst I site is available after the lon gene. As a possible source for a controllable promoter, the plasmids pUC13 and pUC18 offered a multicloning site downstream of an inducible lac promoter. It was found that by cutting the plasmid pUC18 or pUC13 and attaching the SacI-cut DNA fragment containing the lon structural gene, lon would be in the correct reading frame and lon expression would then come under the control of the lac promotor. The resulting expressed protein would be a fusion of protease La with nine additional amino acids attached at the amino-terminus. Such a fusion protein could possess La protease activity.

In one experiment, pUC13 was cut with EcoRI and treated with phosphatase. The plasmid pKF5 was also cut with EcoRI and both DNA fragments were ligated. After ligation the DNA was precipitated and cut with $S a c I$ to remove the $S a c I$ DNA fragment containing the lon promoter. The resulting $9.0 \mathrm{~kb}$ fragment was 
purified by electrophoresis, isolated and religated. Transformation of E. coli DH5 $\alpha$ with the religated fragment produced some ampicillin-resistant transformants, but restriction analysis of isolated plasmid DNA showed that none of them contained the lon gene insert.

After different attempts to clone a regulated promoter in front of the lon gene in pKF5 had failed, a two-step procedure to clone the lon structural gene in pUC18 was attempted. This procedure provides greater definition and control of lon gene insertion into pUC18 than does a single-step approach. It helps to delineate whether difficulty in cloning is the result of some nucleic acid interaction or is associated with the presence of an intact gene (and hence possibly with its expression). In this case the strategy is based on the presence of a $S a l \mathrm{I}$ site within a $S a c \mathrm{I} / P_{s t} \mathrm{I}$ fragment of pKF5 which contains the entire lon gene. In the first step, the $0.95 \mathrm{~kb}$ Sal I/Pst I fragment (called flon2) can be cloned into pUC18 to produce a plasmid designated pUCflon2. The $1.58 \mathrm{~kb} \mathrm{SacI/SalI}$ fragment (flon1) can then be cloned into this plasmid, thus restoring the whole lon gene under the control of the lac promoter.

The plasmid pKF5 was cut with SalI and Pst I and the fragments were separated by gel electrophoresis. The fragment flon 2 was isolated and ligated with the plasmid pUC18 cut with the same restriction enzymes and transformed into E. coli DH5 $\alpha$. Most of the ampicillin-resistant transformations contained the plasmid pUCflon2. To obtain the flon1 fragment, pKF5 was cut with $S a c I$ and $S a l I$ and isolated in the same way as flon2. To clone flon1 into pUCflon2, the plasmid was cut with $S a C I$ and SalI, and the small DNA piece between the two sites was removed by gel electrophoresis. The isolated pUCflon 2 with the two different sticky ends was ligated with flon1 and then transformed into $E$. coli $\mathrm{DH} 5 \alpha$.

When no transformants were obtained after repeating the experiment several times, the construction of pUClon was verified in vitro. To accomplish this, a very large amount (compared with amounts for normal ligation conditions) of $\mathrm{pUCflon} 2$ was mixed with a corresponding large amount of flon1. After ligation, the precipitated DNA was cut with Sall. The fragments were separated by gel electrophoresis and the observed pattern is shown in Fig. 2. The $5.2 \mathrm{~kb}$ fragment, the linearized form of the desired plasmid pUClon, was isolated and religated. A part of the religated DNA was cut with Pst I and analyzed by gel electrophoresis. The pattern showed a band at $3.25 \mathrm{~kb}$ fragment and a $1.95 \mathrm{~kb}$ fragment (Fig. 2). The first corresponded to pUC18 with the attached SacI/Pst I $0.58 \mathrm{~kb}$ fragment of the lon gene, and the second fragment corresponds to the $P_{s t} \mathrm{I} / P_{s t} \mathrm{I} 1.95 \mathrm{~kb}$ fragment of the lon gene. With this analysis the in vitro construction of pUClon was verified.

$E$. coli DH5 $\alpha$ and E. coli JM101 were transformed with the main part of the religated $5.2 \mathrm{~kb}$ fragment. To insure that the $E$. coli cells were competent, parallel transformations with $\mathrm{pUC} 19$ and pUCflon2 were made. Following the transformation protocol, supplied with competent cells by BRL, the transformations with pUC19 and pUCflon2 gave the expected high transformation rate. However, no transformants could be obtained from the transformation with the religated $5.2 \mathrm{~kb}$ fragment. Repeated transformations and changing the medium from S.O.C. and LB to $\mathrm{M} 9$ minimal medium were also unsuccessful with respect to obtaining transfor- 
mants. (Use of minimal medium should prevent loss of the $\mathrm{F}^{\prime}$ episome in JM101 which contains a $l a c I^{q}$ gene to provide extra lac repressor. This episome, which contains a functional pro $A B$ locus, complements a deletion of these genes in the host which blocks proline synthesis). Therefore, it is concluded that, under the conditions described here, transformation by pUClon does not occur in viable cells.

\section{Discussion}

A different spontaneous insertion into the plasmid pJMC40 has been described by Goff and Goldberg (1987). The insertion in their case was a fragment of approximately $800 \mathrm{bp}$ and was inserted into the amino-terminal end of the lon gene. The insertion which was obtained in this work was an approximately 1300 bp DNA fragment which was inserted outside of the lon fragment containing the transcription control region and structural gene. The restriction analysis carried out in this work showed that the distances between the restriction sites in the insert are different to any pattern found in the plasmid. A recombination event between the $E$. coli chromosome and the chromosomal DNA on the plasmid is thus unlikely. Such insertions are not uncommon, but unexpected in a rec-negative strain like $E$. coli HB101.

pJMC40 contains about $14.1 \mathrm{~kb}$ including a $6.7 \mathrm{~kb}$ fragment with lon. pJMC40ins (approximately $15.4 \mathrm{~kb}$ ) contains an $8.0 \mathrm{~kb}$ fragment. As a routine cloning procedure, circularization of the $6.7 \mathrm{~kb}$ Eco RI fragment from pJMC40 containing the lon gene and the origin of replication together with the tetracycline resistance gene of pBR322 was apparently straightforward, and repeated failure was consequently unexpected. Possible reasons for not obtaining transformants include: failure in the expression of the tetracycline resistance genes, failure in plasmid replication, or elevated expression of the lon gene which, as discussed below, is apparently lethal for the cell.

In a similar attempt, Goff and Goldberg (1987) reported that no circularization of the $6.7 \mathrm{~kb}$ fragment could be obtained. The successful circularization of the 8.0 $\mathrm{kb}$ fragment in this work and the expression of the lon gene on that plasmid suggest that there may be some kind of interference between control regions in the $6.7 \mathrm{~kb}$ fragment. The RNA polymerase-binding regions of the tetracycline resistance gene and the lon gene on a circularized $6.7 \mathrm{~kb}$ fragment would only be approximately 340 bp apart. On the circularized $8.0 \mathrm{~kb}$ fragment this distance is enlarged by approximately $1300 \mathrm{bp}$. It is possible that this enlargement may restore normal expression control of the lon and tetracycline resistance genes. Goff and Goldberg reported successful cloning of a circularized $7.5 \mathrm{~kb}$ fragment consisting of the $6.7 \mathrm{~kb}$ fragment with an $800 \mathrm{bp}$ insert in the lon gene. In this case the distances between the control regions remained unchanged, but the lon gene was not functional. This suggests that control of lon gene expression is perturbed in the circularized $6.7 \mathrm{~kb}$ fragment, but an insertion into the lon gene, thus inactivating it, could stabilize the plasmid-host interaction. 
The circularized $8.0 \mathrm{~kb}$ fragment (designated pKF5) was used in several different attempts to clone a controllable promoter in front of the lon gene. The lac promoter was used in most of these experiments because the combination of the lac promoter and the multicloning site of the pUC plasmids allowed establishment of the correct reading frame by cloning at the $S a c I$ site. In some cases the construction was done first in vitro, but none of the attempts resulted in a plasmid in which the lon gene was under control of the lac promoter. One attempt with a trp promoter gene block (results not shown) was also unsuccessful.

When the experiments to change the lon promoter region in pKF5 failed, attempts were made to clone the structural gene of Ion into the plasmid pUC18. The developed two-stage strategy was very convenient, since in both stages the sticky ends were different, and the fragments could consequently be cloned in the right orientation. Moreover religation of the vector is thus not so probable so that phosphatase treatment was unnecessary. However, dimers of the vector were found in almost all experiments, despite the fact that the ratio of fragments was in a range unfavorable for dimer production. The experiment appeared trivial, and there were no problems in cloning one part of the lon gene, a $0.95 \mathrm{~kb}$ fragment designated as flon2, into pUC18. Still all attempts to clone the other part, a $1.58 \mathrm{~kb}$ fragment (designated flon1), failed. To find out if the ligation or the transformation itself caused the failure, the construction of the desired plasmid (pUClon) was carried out and analyzed in vitro. When transforming the pUClon construct, pUC19 and pUCflon 2 were used in parallel to transform the same competent cells. No transformants were obtained using the in vitro pUClon construct, although the parallel experiments with pUC19 and pUCflon2 produced the expected high transformation rate. At this point it became obvious that the induction of the lac promoter, leading to expression of the lon gene, was the crucial point of the negative results.

Normally the expression of the lac system is strictly regulated by the lac repressor. Very few lac repressor molecules are able to reduce lac expression 1000 times compared with the fully-induced single-copy lac operon in wild-type E. coli. Using high copy number plasmids like the pUC vectors, there are inadequate lac repressor molecules and this leads to constitutive induction of the lac promoter. Sometimes this induction can be kept almost at zero by using lacI ${ }^{q}$ strains, which overproduce the repressor (Messing et al., 1981). To keep the induction of lac at a minimal level, the medium for the transformation was changed from a full to a minimal medium. This led to a decrease in transformation efficiency of about 100 to 1000 times for pUC19 and pUCflon2 into competent $E$. coli. To provide high levels of lac repressor, E. coli JM101, which has $l a c I^{q}$ on an episome, was transformed with the in vitro construct of pUClon. Even with these efforts no transformants containing pUClon could be obtained.

Goff and Goldberg (1987) experienced the same difficulties when attempting to clone the lon gene downstream from a lac or tac promotor. They solved the problem by transforming plasmids with the lac- or tac-controlled lon gene into cells, which were overproducing lac repressor carried on a compatible multicopy plasmid within the cells. Our results together with the observations by Goff and Goldberg make it clear that the level of lac repressor molecules has to be very high to prevent 
any induction of the lac promoter and expression of the lon gene. Failure to obtain clones of pUClon in $E$. coli JM101 in minimal medium indicates that elevated repression of a multicopy lac promoter is insufficient to prevent lethal expression of protease La. The sensitivity of $E$. coli to elevated expression of the lon gene must be very high, since the construction of Goff and Goldberg crosses the threshold into nonlethal levels of La.

It is obvious that the controlled expression of the lon gene is essential for the survival of the host cells. The lon gene, as described in the Introduction, is involved in many crucial processes within the cell. Changes in fine tuning of its expression relative to that present for the single-copy chromosomal lon gene leads to lethal disturbances of cell functions.

\section{Acknowledgements}

This research was supported by the Energy Conversion and Utilization Technology (ECUT) program of the U.S. Department of Energy.

\section{References}

Avni, H. and Markovitz, A. (1979) Characterization of a mini ColE1 cloning vector. Plasmid 2, 225-236. Belhumeur, P. and Drapeau, G.R. (1984) Regulation of cell division in Escherichia coli: properties of new fts $Z$ mutants. Mol. Gen. Genet. 197, 254-260.

Birnboim, H.C. and Doly, J. (1979) A rapid alkaline extraction procedure for screening recombinant plasmid DNA. Nucleic Acids Res. 7, 1513-1523.

Bröker, M. (1986) Vectors for regulated high-level expression of proteins fused to truncated forms of Escherichia coli $\beta$-galactosidase. Gene Anal. Techn. 3, 53-57.

Cheng, Y.E., Kwoh, D.Y., Kwoh, T.J., Soltvedt, B.C. and Zipser, D. (1981) Stabilization of a degradable protein by its overexpression in Escherichia coli. Gene 14, 121-130.

Chung, C. and Goldberg, A.L. (1982) DNA stimulates ATP-dependent proteolysis and protein-dependent ATPase activity of protease La from Escherichia coli. Proc. Natl. Acad. Sci. USA 79, 795-799.

Chung, C., Waxman, L. and Goldberg, A.L. (1983) Studies of the protein encoded by the Lon mutation, CapR9, in Escherichia coli. J. Biol. Chem. 258, 215-221.

Edmunds, T. and Goldberg, A.L. (1986) Role of ATP hydrolysis in the degradation of proteins by protease La from Escherichia coli. J. Cell Biochem. 32, 187-191.

Gayda, R.C., Stephens, P.E., Hewick, R., Schoemaker, J.M., Dreyer, W.J. and Markovitz, A. (1985) Regulatory region of the heat shock-inducible capR (lon) gene: DNA and protein sequences. J. Bacteriol. 162, 271-275.

Goff, S.A., Casson, L.P. and Goldberg, A.L. (1984) Heat shock regulatory gene $h t p R$ influences rates of protein degradation and expression of the lon gene in Escherichia coli. Proc. Natl. Acad. Sci. USA 81, $6647-6651$.

Goff, S.A. and Goldberg, A.L. (1985) Production of abnormal proteins in E. coli stimulates transcription of lon and other heat shock genes. Cell 41, 587-595.

Goff, S.A. and Goldberg, A.L. (1987) An increased content of protease La, the lon gene product, increases protein degradation and blocks growth in Escherichia coli. J. Biol. Chem. 262, 4508-4515.

Goldberg, A.L., Swamy, K.H.S., Chung, C.H. and Larimore, F.S. (1981) Proteases in Escherichia coli. Methods Enzymol. 80, 680-691.

Goldberg, A.L. (1985) Role of ATP and protease La, the lon gene product, in protein breakdown in Escherichia coli. In: Leive, L. (Ed.), Microbiology 1985, ASM Washington, DC, pp. 340-345. 
Gottesman, S., Trisler, P., Torres-Cabassa, A. and Maurizi, M.R. (1985a) Regulation via proteolysis: the Escherichia coli lon system. In: Leive, L. (Ed.), Microbiology 1985, ASM Washington DC, pp. 350-354.

Gottesman, S., Trisler, P. and Torres-Cabassa, A. (1985b) Regulation of capsular polysaccharide synthesis in Escherichia coli $K-12$ : characterization of three regulatory genes. J. Bacteriol. 162, $1111-1119$.

Hwang, B.J., Park, W.J., Chung, C.H. and Goldberg, A.L. (1987) Escherichia coli contains a soluble ATP-dependent protease (Ti) distinct from protease La. Proc. Natl. Acad. Sci. USA 84, 5550-5554.

Ish-Horowicz, D. and Burke, J.F. (1981) Rapid efficient cosmid cloning. Nucleic Acids Res. 9 , 2869-2998.

Katayama-Fujimura, Y., Gottesman, S. and Maurizi, M.R. (1987) A multiple-component, ATP-dependent protease from Escherichia coli. J. Biol. Chem. 262, 4477-4485.

Kitano, K., Fujimoto, S., Nakao, M., Watanabe, T. and Nakao, Y. (1987) Intracellular degradation of recombinant proteins in relation to their location in Escherichia coli cells. J. Biotechnol. 5, 77-86.

Lutkenhaus, J., Sanjanwala, B. and Lowe, M. (1986) Overproduction of FtsZ suppresses sensitivity of lon mutants to division inhibition. J. Bacteriol. 166, 756-762.

Maniatis, T., Fritsch, E.F. and Sambrook, J. (1982) Molecular cloning. Cold Spring Harbor Laboratory, Cold Spring Harbor, NY.

Maurizi, M.R., Trisler, P. and Gottesman, S. (1985) Insertional mutagenesis of the lon gene in Escherichia coli: lon is dispensable. J. Bacteriol. 164, 1124-1135.

Messing, J., Crea, R. and Seeburg, P.H. (1981) A system for shotgun DNA sequencing. Nucleic Acids Res. 9, 309-321.

Miller, J.H. (1972) Experiments in molecular genetics. Cold Spring Harbor Laboratory, Cold Spring Harbor, NY.

Rupprecht, K.R. and Markovitz, A. (1983) Conservation of capR (lon) DNA of Escherichia coli K-12 between distantly related species. J. Bacteriol. 155, 910-914.

Schoemaker, J.M. and Markovitz, A. (1981) Identification of the gene lon (capR) product as a 94-kilodalton polypeptide by cloning and deletion analysis. J. Bacteriol. 147, 46-56.

Simon, L.D., Tomczak, K. and St. John, A.C. (1978) Bacteriophages inhibit degradation of abnormal proteins in E. coli. Nature 275, 424-426.

Trisler, P. and Gottesman, S. (1984) Lon transcriptional regulation of genes necessary for capsular polysaccharide synthesis in Escherichia coli K-12. J. Bacteriol. 160, 184-191.

Truitt, C.L., Haldenwang, L.G. and Walker, J.R. (1976) Interaction of host and viral regulatory mechanisms: effect of the lon cell division defect on regulation of repression by bacteriophage Lambda. J. Mol. Biol. 105, 231-244.

Vieira, J. and Messing, J. (1982) The pUC plasmids, an M13mp7-derived system for insertion mutagenesis and sequencing with synthetic universal primers. Gene 19, 259-268.

Yanisch-Perron, C., Vieira, J. and Messing, J. (1985) Improved M13 phage cloning vectors and host strains: nucleotide sequence of the M13mp18 and pUC19 vectors. Gene 33, 103-119.

Zehnbauer, B.A. and Markovitz, A. (1980) Cloning of gene lon (capR) of Escherichia coli K-12 and identification of polypeptides specified by the cloned deoxyribonucleic acid fragment. J. Bacteriol. $143,852-863$.

Zehnbauer, B.A., Foley, E.C., Henderson, G.W. and Markovitz, A. (1981) Identification and purification of the Lon $+(\operatorname{cap} R+)$ gene product, a DNA-binding protein. Proc. Natl. Acad. Sci. USA 78, 2043-2047.

Zipser, D. and Bhavsar, P. (1976) Missense mutations in the lacZ gene that result in degradation of $\beta$-galactosidase structural protein. J. Bacteriol. 127, 1538-1542. 